\title{
Study of the mechanical properties of low carbon content HSLA steels $(\cdot)$
}

\author{
S. Illescas*, J. Fernández*, J. Asensio**, M. Sánchez-Soto*** and J.M. Guilemany*
}

\begin{abstract}
Two high strength low alloy steels (HSLA) with the same bulk composition and slight microalloying content differences were studied. The main purpose of the study was to determine the effect of different heat treatments and the influence of vanadium $(\mathrm{V})$ on the microstructure and mechanical properties of the bainite present in each steel. For that purpose, standard tests were conducted to determine the hardness, toughness, tensile and yield stress of the different bainite-acicular ferrite structures found in both steels. The results show how the $V$ content promoted the formation of acicular ferrite, resulting in a decrease in hardness and tensile strength while improving toughness.
\end{abstract}

Keywords $\quad$ HSLA steel; Microalloying; Bainite; Acicular ferrite; Mechanical properties.

\section{Estudio de las propiedades mecánicas de aceros HSLA de bajo contenido en carbono}

Se han estudiado dos aceros HSLA (high strength low alloy) que presentan composiciones similares, a excepción
del contenido en elementos microaleantes. El propósito del estudio es determinar el efecto del tratamiento térmico
y la influencia del contenido en vanadio $(V)$ sobre la microestructura y las propiedades mecánicas de la bainita en ca-
da uno de los aceros. Para ello, se han realizado ensayos de dureza, de impacto y de tracción para cada una de las es-
tructuras bainíticas-ferrita acicular obtenidas por medio de los diferentes tratamientos térmicos realizados. Los re-
sultados muestran como el contenido en $V$ promueve la formación de ferrita acicular, presentando valores bajos de du-
reza y resistencia mecánica pero mejorando la tenacidad.

Palabras clave HSLA; Mmicroaleante; Bainita; Ferrita acicular; Propiedades mecánicas.

\section{INTRODUCTION}

In some markets, such as the automotive component sector, there is a need to increase the strength of steel and at the same time reduce its weight. The combination of strength and impact resistance is also important ${ }^{[1]}$. High strength low alloy steel (HSLA), with an excellent combination of strength, toughness and weldability, has been developed over the last two decades to replace conventional medium carbon steels ${ }^{[2 \text { and } 3]}$. Among the most typical microalloying HSLA elements are titanium, niobium and vanadium for grain refinement and carbide precipitation hardening ${ }^{[4]}$.

Bainite and acicular ferrite form in the same range of temperatures, particularly below the temperature formation of allotriomorphic ferrite and pearlite, and above the martensite-start one. Their mechanism of formation, considered similar for both phases, is still subject of discussion ${ }^{[5-9]}$. The main difference between both phases is in their nucleation: while bainite is nucleated at austenite grain boundaries, acicular ferrite is intragranularly nucleated at the non-metallic inclusions present in the stee ${ }^{[10-12]}$. The nucleated

(•) Trabajo recibido el día 7 de enero de 2009 y aceptado en su forma final el día 29 de julio de 2009.

* Departament de Ciència dels Materials i Enginyeria Metal·lúrgica, Facultat de Química, Universitat de Barcelona, Martí i Franquès 1, 7a planta, 08028 Barcelona, España.

** Departamento de Ciencia de los Materiales e Ingeniería Metalúrgica, E.T.S. de Ingenieros de Minas, Universidad de Oviedo, Independencia 13, $1^{\text {a }}$ planta, 33004 Oviedo, España.

*** Departament de Ciència dels Materials i Enginyeria Metal·lúrgica, E.T.S.E. Industrial i Aeronàutica, Universitat Politècnica de Catalunya, Colom 11, 08222 Terrassa, España. 
ferrite present in bainite forms groups of parallel plates with the same crystallographic orientation. Meanwhile, acicular ferrite microstructures lead to a random arrangement of plates. In particular, acicular ferrite is characterized by fine-grained interlocking morphologies ${ }^{[5}$ and 10-14].

A reduction of the austenite surface per volume grain boundary favours the formation of acicular ferrite due to a decrease in bainite nucleation sites ${ }^{[15}$ and 16$]$. A similar effect can be obtained by increasing the number of inclusions present in the stee ${ }^{[17 \text { and } 18]}$ and also with the addition of vanadium as a microalloying ${ }^{[19]}$.

The studies about the formation of acicular ferrite show two different steps: 1) first, the nucleation of the primary plates occurs at the non-metallic inclusions of various types of compounds and compositions, for instance oxides, sulphides and nitrides ${ }^{[20}$ and 21] , and 2) secondly a new generation of secondary plates nucleate at the interfaces of the austenite/acicular ferrite primary plates ${ }^{[22]}$, resulting in its random-like nature ${ }^{[23]}$.

Studies on the microstructure of acicular ferrite have been carried out preferentially on welds and low carbon steels and recently medium-carbon microalloyed forging steels were studied ${ }^{[22,24}$ and 25].

In this study, two low carbon HSLA steels were studied. These steels present a similar composition except in the microalloying content ( $\mathrm{V}$ and $\mathrm{Nb}$ ). Different heat treatments were used in order to obtain different bainitic/acicular ferrite structures. The effect of the $\mathrm{V}$ content on the microstructure and properties was also evaluated.

\section{EXPERIMENTAL PROCEDURE}

Two low carbon HSLA steels, $16 \mathrm{MnNi} 4$ and $16 \mathrm{Mn} 4$, were studied. Table I shows the chemical composition of the base materials, which were provided as $10 \mathrm{~mm}$ thick rolls.

A previous work was dedicated to the optimization of the austenization conditions of the different samples in order to obtain the lowest possible homogeneous grain size ${ }^{[26}$ and 27$]$. The $16 \mathrm{MnNi} 4(\mathrm{~V}+\mathrm{Nb})$ and $16 \mathrm{Mn} 4$
(V) samples were respectively austenized at $1,050^{\circ} \mathrm{C}$ during $30 \mathrm{~min}$ and $15 \mathrm{~min}$ at $1,000^{\circ} \mathrm{C}$. The austenite grain size obtained under these conditions was of 16 $\mathrm{m}$ for the $\mathrm{V}+\mathrm{Nb}$ steel and $27 \mu \mathrm{m}$ for the $\mathrm{V}$ steel.

After the austenization, bainite was formed by immersing the samples in a molten salts bath $\left(\mathrm{KNO}_{3}\right.$ $/ \mathrm{NaNO}_{3}, 1: 1$ ) at a temperature between 350 and $500{ }^{\circ} \mathrm{C}$ and for times ranging from 30 to $60 \mathrm{~min}$.

Micrographs of the samples were obtained by using an Olympus BH2-UMA light optical microscope (LOM) and a JEOL 5510 scanning electron microscope (SEM). The microstructures were revealed by etching with $5 \%$ of Nital. The volume fractions of the constituents found after the heat treatment were evaluated by the point counting method using a grid with 400 points according to ASTM E562. This is a method for determining the volumetric composition of a solid by observing the frequency at which areas of each component coincide with a regular system of points in one or more planes intersecting a sample of the solid.

Transmission electron microscopy (TEM) observations were made using a CM30 microscope operating at $200 \mathrm{kV}$. Thin foils were prepared using a twin-jet polisher at $40 \mathrm{~V}$-dc, with an electrolyte composition of $4 \%$ perchloric in acetic acid.

Microhardness measurements were performed according to UNE ISO 6507-2. Both the 0.2 percent offset yield stress and tensile strength were determined according to EN 1002. Finally, toughness was evaluated using the Charpy test (EN 100045).

\section{RESULTS AND DISCUSSION}

\subsection{Microstructural characterization}

The starting materials were two hot rolled plates with a ferrite plus pearlite microstructure, as shown in figure 1.

Bainitic plus acicular ferrite structures were obtained after the previously mentioned heat treatments. A microstructure containing upper and

Table I. Chemical composition of the studied steels (wt.\%)

Tabla I. Composición química de los aceros estudiados (\% en peso)

\begin{tabular}{ccccccccccccccc}
\hline $\mathrm{C}$ & $\mathrm{Mn}$ & $\mathrm{Si}$ & $\mathrm{Cr}$ & $\mathrm{Ni}$ & $\mathrm{Mo}$ & $\mathrm{V}$ & $\mathrm{Nb}$ & $\mathrm{Al}$ & $\mathrm{Ti}$ & $\mathrm{Cu}$ & $\mathrm{P}$ & $\mathrm{S}$ & $\mathrm{N}$ \\
\hline $16 \mathrm{MnNi4}(\mathrm{V}+\mathrm{Nb})$ & 0.165 & 1.11 & 0.23 & 0.02 & 0.34 & 0.001 & 0.026 & 0.0135 & 0.0244 & 0.0014 & 0.184 & 0.015 & 0.0022 & 0.0059 \\
\hline $16 \mathrm{Mn4}(\mathrm{V})$ & 0.166 & 1.24 & 0.16 & 0.02 & 0.02 & 0.001 & 0.051 & 0 & 0.0309 & 0 & 0.186 & 0.015 & 0.0151 & 0.0027 \\
\hline
\end{tabular}



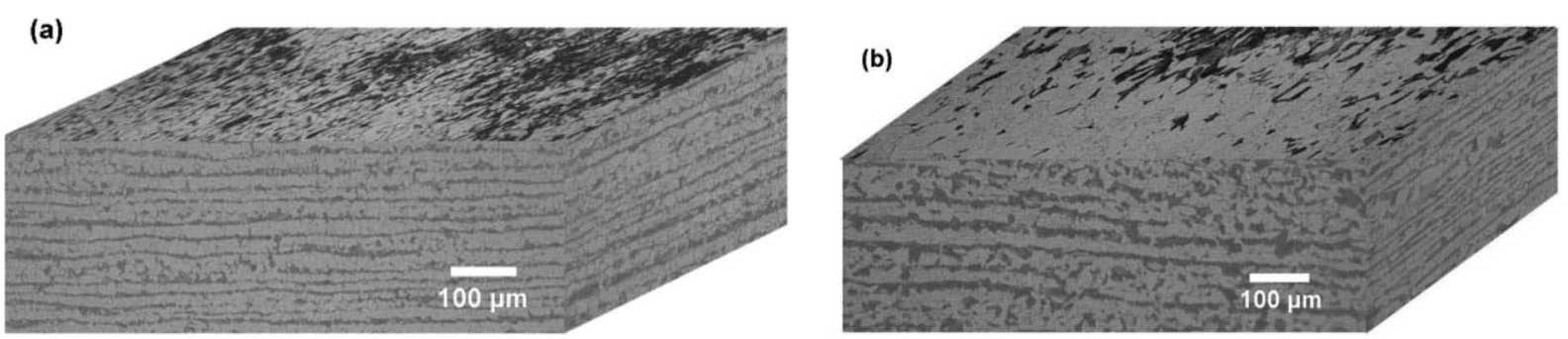

Figure 1. LOM micrographs showing the ferrite plus pearlite microstructure for the initial as-rolled steels. (a) V+Nb steel and (b) V steel.

Figura 1. Microscopia óptica que muestra la estructura de ferrita más perlita para los materiales de partida que fueron suministrados con placas de acero laminado en caliente. (a) Acero V+Nb y (b) Acero V.

lower bainite and with the presence of acicular ferrite was obtained for each steel, as shown in the micrographs of figure 2 .

The LOM micrographs allowed to determine the amount of acicular ferrite. This phase presents a different morphology, with a fine-grained appearance compared to the bigger parallel plate-like bainite. From these morphological differences, it was possible to calculate the amount of acicular ferrite, although LOM did not allow to distinguish between upper and lower bainite (previously, quantitative characterization of these steels was considered using TEM ${ }^{[28]}$ ). In this study we have just evaluated the acicular ferrite content without differentiating between upper and lower bainites. The results of the acicular ferrite volume fraction, evaluated by the point counting method, are presented in figure 3 .

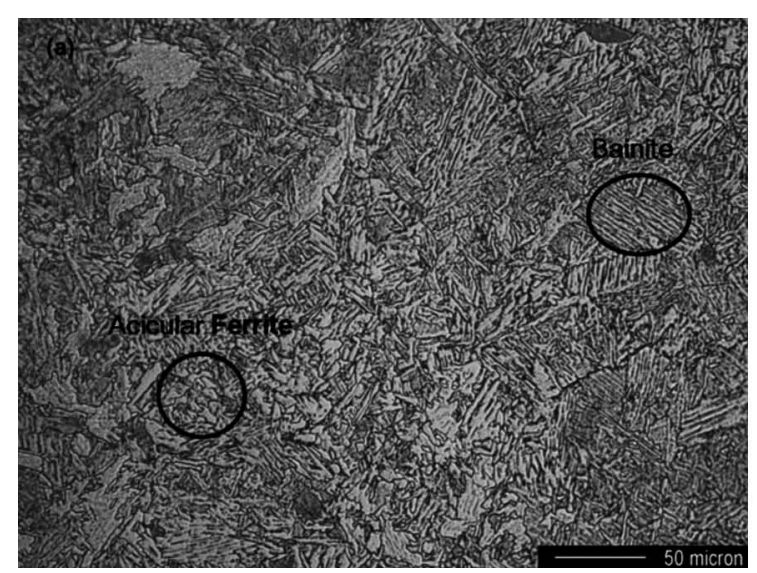

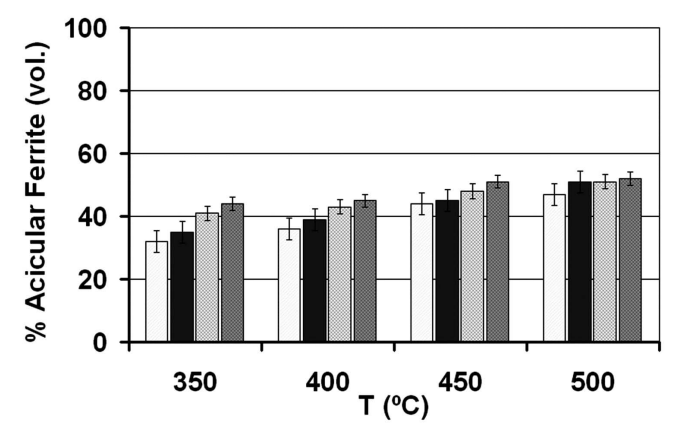

$\square \mathrm{V}+\mathrm{Nb}, 30 \mathrm{~min} \square \mathrm{V}+\mathrm{Nb}, 60 \mathrm{~min} \square \mathrm{V}, 30 \mathrm{~min} \square \mathrm{V}, 60 \mathrm{~min}$

Figure 3. Volume fraction of acicular ferrite for the different heat treated steels.

Figura 3. Fracción en volumen de ferrita acicular para los diferentes tratamientos térmicos y aceros.

Figure 2. Typical bainite plus acicular ferrite microstructures obtained after the following heat treatments: (a) LOM micrograph of $\mathrm{V}+\mathrm{Nb}$ steel treated at $450{ }^{\circ} \mathrm{C}$ during $30 \mathrm{~min}$, (b) SEM micrograph of the $\mathrm{V}+\mathrm{Nb}$ steel treated at $450{ }^{\circ} \mathrm{C}$ during $30 \mathrm{~min}$.

Figura 2. Ejemplo de microestructuras de bainita con ferrita acicular (microestrustura típica obtenida tras realizar los tratamientos térmicos descritos): (a) Micrografía de LOM del acero V+Nb tratado a $450^{\circ} \mathrm{C}$ durante $30 \mathrm{~min}$, (b) Micrografía de SEM del acero $\mathrm{V}+\mathrm{Nb}$ tratado a $450^{\circ} \mathrm{C}$ durante $30 \mathrm{~min}$. 
The graph shows that the $V$ steel presents a higher acicular ferrite content than the $\mathrm{V}+\mathrm{Nb}$ due to its higher grain size, favouring the development of a high volume fraction of lower bainite for the high number of available nucleation sites ${ }^{[29]}$, and also to a higher vanadium content, that promotes the formation of acicular ferrite ${ }^{[19]}$.

\subsection{Microhardness}

Microhardness tests were performed on the two steels after isothermal treatments for 30 and $60 \mathrm{~min}$. Figure 4 shows the microhardness results for the different samples.

There is a decrease in the microhardness with increasing the temperature, which is consistent with the development of lower bainite below $500^{\circ} \mathrm{C}$, as reported in a former work ${ }^{[28]}$.

The graph also shows the hardness values of the $\mathrm{V}$ steel to be somewhat lower than that of the $\mathrm{V}+\mathrm{Nb}$.

Reciprocally, high $\mathrm{V}$ contents enhance the occurrence of a higher proportion of acicular ferrite, thus resulting in a softer material.

It is a common feature that a hardness peak is reached for both steels with $60 \mathrm{~min}$ of treatment. A convergence in hardness values at $500^{\circ} \mathrm{C}$ is observed for the two steels.

The hardness values obtained for the $\mathrm{V}+\mathrm{Nb}$ steel are independent of the duration of the heat treatment, while the $\mathrm{V}$ steel shows differences with increasing the time from 30 to $60 \mathrm{~min}$.

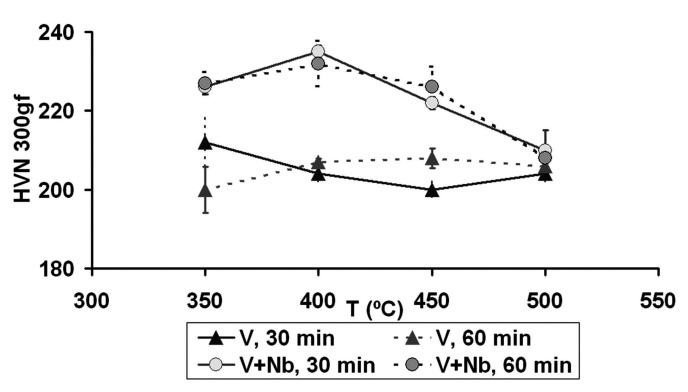

Figure 4. Evolution of the microhardness measured at 300gf (HVN 300gf) as a function of the heat treatment temperature for the different steels and times.

Figura 4. Evolución de los valores de microdureza a 300gf (HVN 300gf) de las muestras en función de la temperatura de tratamiento térmico para los diferentes aceros y tiempos de tratamiento térmico.

\subsection{Charpy test}

Impact fracture testing was conducted to ascertain the fracture characteristics of the material. The Charpy V-notch test (CVN) technique was selected to measure the impact energy of the base and respective heat treated materials.

First of all, the Charpy curves are presented for the initial materials. Figure 5 shows the ductile-brittle curve for each of the steels from which the ductilebrittle temperature transition was determined.

The temperature curve of the Charpy V-notch impact energy for the two materials in the as-rolled condition exhibits high values of absorbed energy in the ductile region: $225 \mathrm{~J}$ for the $\mathrm{V}+\mathrm{Nb}$ steel and around $175 \mathrm{~J}$ for the $\mathrm{V}$ steel. Also, the $\mathrm{V}$ steel shows a clear ductile-brittle transition with fully brittle behaviour at and below $-50^{\circ} \mathrm{C}$, with an absorbed energy of around $40 \mathrm{~J}$. The transition between both behaviours occurs at around $-40^{\circ} \mathrm{C}$.

In the case of the $\mathrm{V}+\mathrm{Nb}$ steel, the curve does not present the classical "S"-shape, but an upper and intermediate plateaus, both corresponding to high absorbed energies in the ductile region at test temperatures above $-60^{\circ} \mathrm{C}$.

Charpy tests were also performed on the bainiticferritic acicular structures once the ductile-brittle transition was established in order to study the brittle and ductile behaviour of the materials. The $\mathrm{V}+\mathrm{Nb}$ steel was tested at $-60,-20$ and $0^{\circ} \mathrm{C}$, and the $\mathrm{V}$ steel at $-50,-20$ and $-10^{\circ} \mathrm{C}$. The results obtained for the different heat treatments are presented in Figure 6.

A big difference was observed for the absorbed energy values at -20 and $-10^{\circ} \mathrm{C}$ for the $\mathrm{V}$ steel. However, after $30 \mathrm{~min}$, no considerable differences were observed when comparing different heat treatments performed at the same test temperature. Significant differences were only ascertained for longer times (60 min).



Figure 5. Charpy curves for $\mathrm{V}+\mathrm{Nb}$ and $\mathrm{V}$ steels.

Figura 5. Curvas Charpy para ambos aceros. 


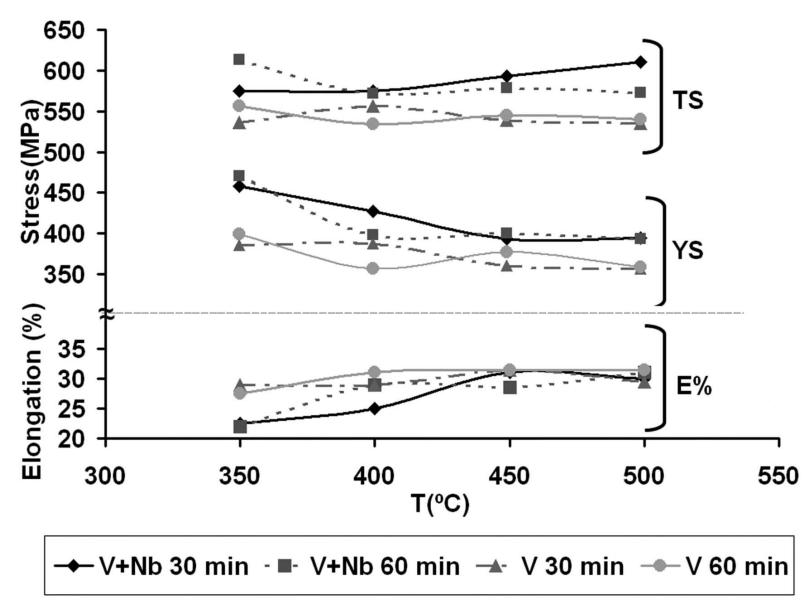

Figure 6. Charpy test results at different test temperatures and heat treatments for (a) $\mathrm{V}+\mathrm{Nb}$ steel and (b) $\vee$ steel.

Figura 6. Resultados de los ensayos de Charpy a diferentes temperaturas de ensayo para cada acero y tratamiento térmico realizado. (a) Acero V+Nb y (b) Acero V.

The energy values of the $\mathrm{V}+\mathrm{Nb}$ steel were lower with decreasing the test temperature. The absorbed energy decreased for the $\mathrm{V}+\mathrm{Nb}$ steel for all the heat treatments when compared with the as-rolled steel (for example, at $0{ }^{\circ} \mathrm{C}$ the absorbed energy was $15 \%$ lower than that of the initial material). The same behaviour was observed for the $\mathrm{V}$ steel tested at $-20^{\circ} \mathrm{C}$. However, the $\mathrm{V}$ steel heat treated at $-10^{\circ} \mathrm{C}$ during $30 \mathrm{~min}$ showed an absorbed energy increase of $24 \%$ with respect to the as-rolled material tested at the same temperature.

Generally speaking, a decrease in the absorbed energy values around $14 \%$ was observed for all the samples and for both steels with increasing the heat treatment time. This is due to the growth of carbides present in the bainitic samples. An exception to this behaviour was the $\mathrm{V}$ steel treated at $450^{\circ} \mathrm{C}$, which showed an absorbed energy independent of the heat treatment time.
Comparing the results at different test temperatures, an absorbed energy decrease was observed when the test temperature increased for the $\mathrm{V}+\mathrm{Nb}$ steel, the decrease being lower as with the ductile-brittle curve for the as-rolled steel. The samples obtained at $500{ }^{\circ} \mathrm{C}$ showed a greater decrease in the absorbed energy values when the test temperature increased due to their high upper bainite content. However, the decrease was quite low and gradual for the samples treated at $350^{\circ} \mathrm{C}$, related to a structure with a high content of a high toughness constituent such as lower bainite.

An abrupt decrease in the absorbed energy was observed at $-20^{\circ} \mathrm{C}$ for the $\mathrm{V}$ steel, with similar values for all the samples. Although the higher absorbed energy at $-50^{\circ} \mathrm{C}$, all the heat treated steels presented a worse behaviour at $-20^{\circ} \mathrm{C}$ compared to the as-rolled materials.

\subsection{Tensile properties}

Table II shows the main tensile results obtained for the untreated initial materials while figure 7 represents the tensile characterization of the bainitic samples.

For $\mathrm{V}+\mathrm{Nb}$ steel, the tensile strength and yield stress increased and the total elongation decreased for all the heat treated specimens when compared to the neat materials. Moreover, an increase in the time of heat treatment resulted in a higher ductility and lower yield stress, except at $350^{\circ} \mathrm{C}$. The condition of maximum ductility after heat treatment for the $\mathrm{V}+\mathrm{Nb}$ steel was reached at $500^{\circ} \mathrm{C}$, the elongation values being similar to those obtained for the as-rolled steel. Also, both the tensile strength and yield stress were higher, showing an improvement in static toughness (total area below the tensile curve).

This improvement in tensile strength and yield stress was smaller for the $\mathrm{V}$ steel than for the $\mathrm{V}+\mathrm{Nb}$, the ductility being practically constant and independent of the heat treatment. The maximum

Table II. Main tensile test results for the as-rolled $\mathrm{V}+\mathrm{Nb}$ and $\mathrm{V}$ steels.

Tabla II. Resultados de los ensayos de tracción para los aceros $\mathrm{V}+\mathrm{Nb}$ y $\mathrm{V}$ en condiciones de recepción (laminados en caliente).

\begin{tabular}{lcccccc}
\hline & \multicolumn{3}{c}{ (V-Nb) steel } & \multicolumn{3}{c}{ (V) steel } \\
\hline & TS (MPa) & YS (MPa) & A (\%) & TS (MPa) & YS (MPa) & A (\%) \\
\hline Initial Material & 548 & 385 & 34 & 544 & 385 & 30 \\
\hline
\end{tabular}




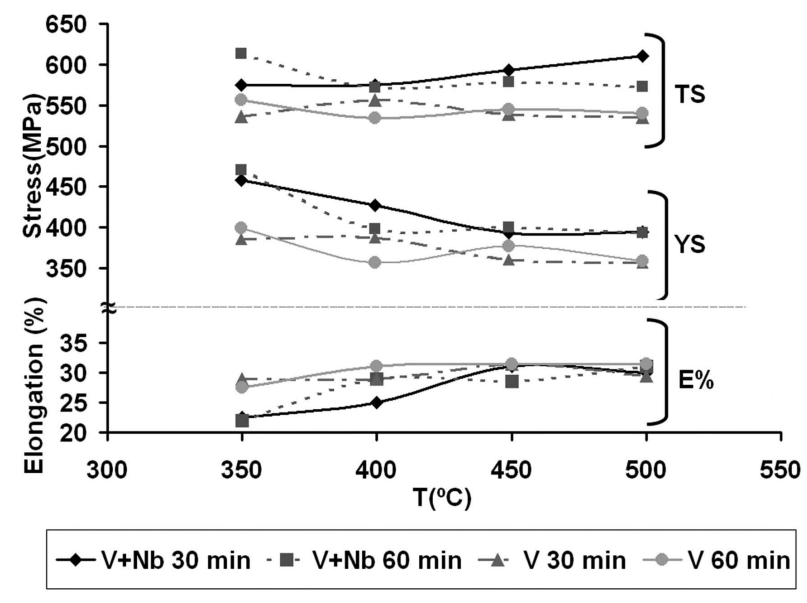

Figure 7. Tensile strength (TS), yield stress (YS) and elongation ( $\mathrm{E} \%$ ) results for the bainitic structures of $\mathrm{V}+\mathrm{Nb}$ and $\mathrm{V}$ steels as a function of the heat treatment temperature.

Figura 7. Resultados de Resistencia a la Tracción (TS), Límite Elástico (YS) y Elongación (E\%) obtenidos a partir de los ensayos de tracción para las estructuras bainíticas de los aceros $\mathrm{V}+\mathrm{Nb}$ y $\mathrm{V}$, en función de la temperatura de tratamiento térmico.

plastic deformation strength was obtained for the sample treated at $350^{\circ} \mathrm{C}$ during $60 \mathrm{~min}$, in agreement with the low elongation decrease.

The decrease in ductility after the heat treatment was greater for the $\mathrm{V}+\mathrm{Nb}$ steel than for the $\mathrm{V}$ steel, the $\mathrm{V}$ samples being globally tougher compared to the $\mathrm{V}+\mathrm{Nb}$ ones after heat treatment.

The strength values between low and high temperature treated materials were different in the $\mathrm{V}+\mathrm{Nb}$ steel due to the presence of upper bainite at temperatures higher than $500{ }^{\circ} \mathrm{C}{ }^{[28]}$. This upper bainite lead to a lower steel strength than where there was lower bainite. This was also due to the high acicular ferrite content observed at high temperatures.

For the $\mathrm{V}$ steel no significant differences were found. The values were always lower compared to $\mathrm{V}+\mathrm{Nb}$. The addition of vanadium, though might enhance the toughness by controlling the microstructure of the acicular ferrite [19 and 30], promoted a decrease in the strength of the steel.

\subsection{Study of precipitates (TEM)}

Considering the importance of the precipitation behaviour of microalloying such as carbide, nitride or carbonitrides, qualitative TEM characterization of the microstructures was considered, as shown in figure 8 . The observation of the different samples showed the presence of $(\mathrm{TiV}) \mathrm{C}$ and $\mathrm{VC}$ precipitates in the $\mathrm{V}$ steel and the existence of $(\mathrm{TiV}) \mathrm{C}$ and $\mathrm{VN}$ precipitates in the $\mathrm{V}+\mathrm{Nb}$ steel. The size of the precipitates was around $50-100 \mathrm{~nm}$. The presence of these precipitates promoted the formation of acicular ferrite in the different samples.

\section{CONCLUSIONS}

In accordance with the information given above, the following conclusions could be drawn:

- The V steel, due to its high acicular ferrite content, presented an improved toughness, together with low hardness and tensile strength values.

- The $\mathrm{V}+\mathrm{Nb}$ and $\mathrm{V}$ steels presented different ductile-brittle curves with a more abrupt increase in the transition temperature for the $\mathrm{V}$ steel, as well as in the total amount of absorbed energy.

- The Charpy test showed a decrease in the absorbed energy values of the $\mathrm{V}+\mathrm{Nb}$ steel and an increase of the $\mathrm{V}$ steel compared to the initial as-rolled steels. A decrease of this energy value was also observed with increasing the heat treatment time.

\section{Acknowledgments}

S. Illescas gratefully thanks the Generalitat de Catalunya for the grant 2003F100470 and project 2005 SGR 00310. She also wishes to thank Metalogenia S.A. for the Charpy tests.

\section{REFERENCES}

[1] M.J. Balart, C.L. Davis and M. Strangwood, Mater. Sci. Eng. A328 (2002) 48-57.

[2] C.I. Garcia, A.K. Lis, S.M. Pytel and A.J. Deardo, Ironmak. Steelmak. 18 (1991) 97-106.

[3] K. Hulka, F. Hesterkamp and L. Nachtel, Processing, Microstructure and Properties of HSLA Steels, TMS, Warrendale, 1988, pp. 153.

[4] J.P. Wang, Z.-G. Yang, B.Z. Bai and H.S. Fang, Mater. Sci. Eng. A 369 (2004) 112-118.

[5] H.K.D.H Bhadeshia, Bainite in Steels, The Institute of Materials, 2nd ed, London, England, 2001.

[6] H.K.D.H. Bhadeshia and J.W. Christian, Metall. Trans. A 21 (1990) 767-797. 

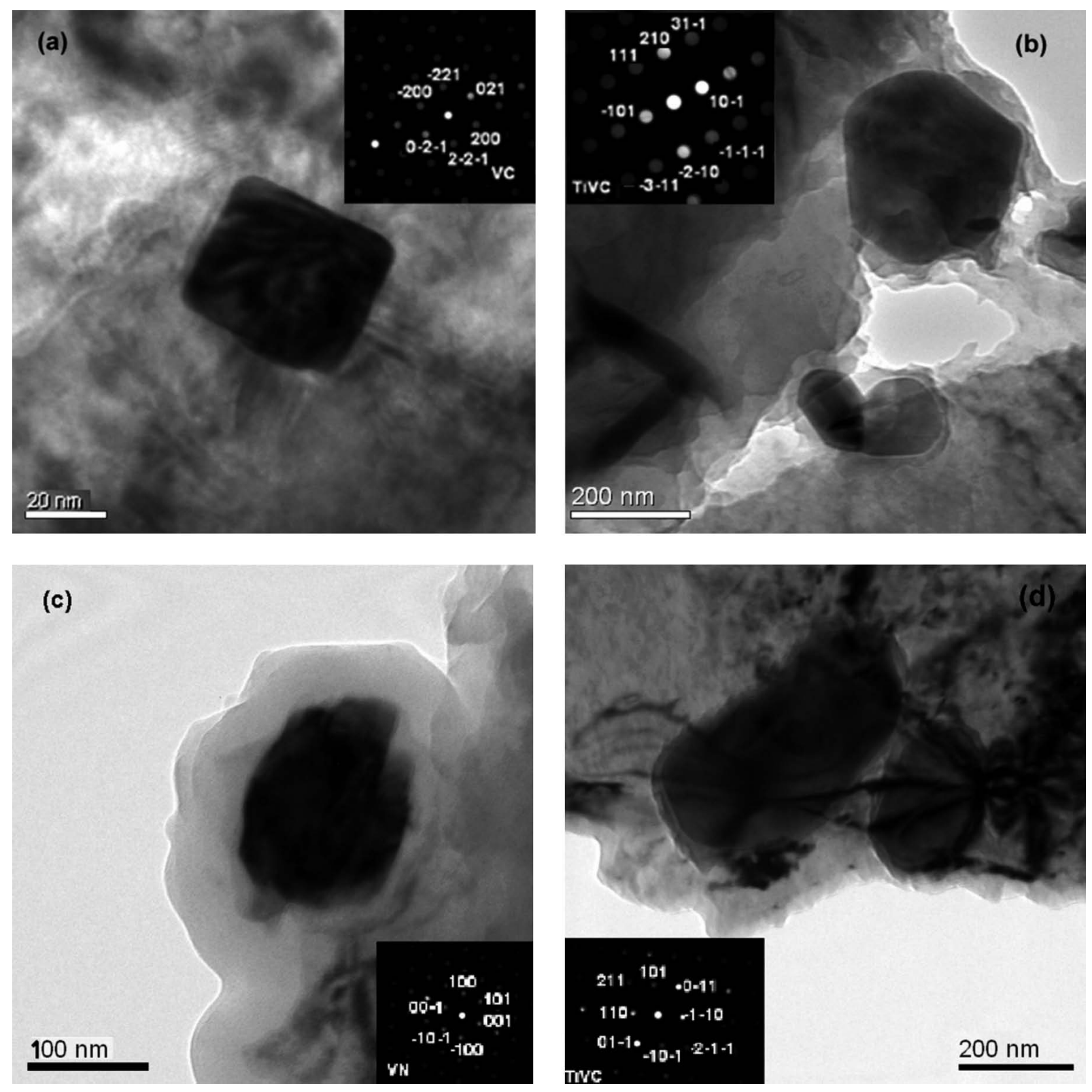

Figure 8. TEM micrographs showing the microalloying precipitates: (a) VC in the V steel, (b) (TiV)C in the $\mathrm{V}$ steel, (c) VN in the $\mathrm{V}+\mathrm{Nb}$ steel, and (d) (TiV) C in the $\mathrm{V}+\mathrm{Nb}$ steel.

Figura 8. Micrografías de TEM mostrando los precipitados de los elementos de microaleación en las muestras. (a) VC en el acero V, (b) (TiV)C en el aceroV, (c) VN en el acero V+Nb, y (d) (TiV)C en el aceroV+Nb.

[7] H.I. Aaronson Jr., W.T. Reynolds, G.J. Shiflet and G. Spanos, Metall. Trans. A 21 (1990) 1343-1380.

[8] M. Hillert, Scripta Mater. 47 (2002) 137-138.

[9] Y. Ohmori, Y.C. Jung, K. Nakai and H. Shioiri, Acta Mater. 49 (2001) 3149-3162.

[10] J.R. Yang and H.K.D.H. Bhadeshia, Mater. Sci. Technol. 5 (1989) 93-97.

[11] R.A. Ricks, P.R. Howell and G.S. Barrite, J. Mater. Sci. 17 (1982) 732-740.
[12] I. Madariaga, I. Gutiérrez and H.K.D.H. Bhadeshia, Metall. Trans. A 32 (2001) 2187-2197.

[13] H.I. Aaronson and C. Wells, Trans. AIME. 206 (1956) 1216-1223.

[14] E. Sarta Kumar-Menon and H.I. Aaronson, Acta Mater. 35 (1987) 549-563.

[15] F. J. Barbaro, P. Kraulis and K. E. Easterling, Mater. Sci. Technol. 5 (1989) 1057-1068.

[16] R. A. Farrar, Z. Zhang, S. R. Bannister and G. S. Barritte, J. Mater. Sci. 28 (1993) 1385-1390. 
[17] Z. Zhang and R. A. Farrar, Mater. Sci. Technol. 12 (1996) 237-260.

[18] D. J. Abson and R. E. Dolby, Weld. Inst. Res. Bull. 19 (1987) 202-207.

[19] K. He and D. V. Edmonds, Mater. Sci. Technol. 1 (2002) 289-292.

[20] J.M. Gregg and H.K.D.H. Bhadeshia, Acta Mater 45 (1997) 739-748.

[21] F. Ishikawa, T. Takahashi and T. Ochi, Metall. Mater. Trans. A 25 (1994) 929-936.

[22] M. Díaz-Fuentes and I. Gutiérrez, Mater. Sci. Eng. A 363 (2003) 316-324.

[23] T. Zhenghua and S. Stumpf, Mater. Charact. 59 (2008) 717-728
[24] I. Madariaga and I. Gutiérrez, Acta Mater. 47 (1999) 951-960.

[25] I. Madariaga and I. Gutiérrez and J.L. Romero, Metall. Trans. A 29 (1998) 1003-1015.

[26] J. Fernández, S. Illescas and J.M. Guilemany, Mater Lett. 61 (2006) 2389-2392.

[27] S. Illescas, J. Fernández and J.M. Guilemany, Rev. Met. Madrid 44 (2008) 39-51.

[28] S. Illescas, J. Fernández and J.M. Guilemany, Prakt. Metallogr. 44 (2007) 334-346.

[29] S.S. Babu and H.K.D.H. Bhadeshia, Mater. T. JIM 32 (1991) 679-688.

[30] N. Tsunekage, K. Kobayashi and H. Tsubakino, Mater. Sci. Technol. 17 (2001) 847-855. 